\title{
An Exploration into the Pedagogical Benefits of Using Social Media: Can Educators Incorporate Social Media into Pedagogy Successfully?
}

\author{
A work in progress
}

\section{Ryan Thomas Williams}

Ph.D. Student, School of Social Sciences, Humanities and Law, Teesside University, Middlesbrough, Tees Valley, TS1 3BX, United Kingdom

*Corresponding Contact:

Email: ryan.williams@tees.ac.uk

Manuscript Received: 29 Aug $2020 \quad$ - Revised: 15 Oct $2020 \quad$ - Accepted: 18 Nov 2020

\begin{abstract}
Many social networking sites have been thought to break down traditional hierarchies in terms of society and global geography (Lewis, 2017). As an example, Twitter empowers learners to engage with individuals from all over the world, often sharing educational resources for free. This 'work in progress' paper adopts a mixed-methods model to explore if social media can be incorporated successfully with pedagogy. In total, 431 participants took part in this study. Of those, 411 completed the survey, and 20 were subjects in the interviews. Teachers described professional reasons and social reasons why they do not use social media regularly in their pedagogy. One emerging theme is that CPD appears to be underdeveloped in this area, as teachers' report that TEL training focuses on administrative uses of a product rather than pedagogical benefits. This has implications on how social media could be used as a pedagogical tool and addresses gaps in the literature in this area. This direction of social media in the classroom remains unclear, however, this study aims to offer a framework for educators when using social media strategies.
\end{abstract}

Keywords: Pedagogy, Social Media, Educator

This article is is licensed under a Creative Commons Attribution-NonCommercial 4.0 International License.

Attribution-NonCommercial (CC BY-NC) license lets others remix, tweak, and build upon work non-commercially, and

although the new works must also acknowledge \& be non-commercial.

\section{INTRODUCTION}

The ubiquity of social media including Facebook and Twitter is no more apparent than in the education industry (Tess, 2013). Drawing on anecdotal evidence, pupils arrive at school and instantly recall last night's social media activities. Nevertheless, in learning contexts, few schools take advantage of how children become enthused and the potential these platforms may have. Ferguson (2013) reports that many teachers are not implementing any social media strategies into their classrooms. Schools have introduced 
$21^{\text {st }}$ century technology into their classrooms with little, if any alteration to the delivery of information. Many social networking sites have been thought to break down traditional hierarchies in terms of society and global geography (Lewis, 2017). As an example, Twitter empowers learners to engage with individuals from all over the world, often sharing educational resources for free. The benefits of using Twitter and the growing role it has on education accelerates debates in how best it can be used to promote learning and improve engagement (Lewis, 2017).

Social media influences $21^{\text {st }}$ century operations and whether referenced with communications, business practice or education, social media is at the heart of the modern-day individual. Almost all industries including corporations, non-profit and government organizations share the need for employees to have social media expertise (see Freberg \& Kim, 2017). Within education, few schools have implemented social media strategies in their learning programs, and at times the topic is often ignored. The main reasons for this are outlined by Fox (2013) and include a) the ambiguity of how to implement technology effectively, b) accessibility to all students and c) does the potential outcome outweigh the additional workload? It is also possible that the absence of social media in the classroom could have a detrimental impact on the future workforce due to the benefits that a social media savvy employee may bring.

The focus of this thesis is to understand if educators can incorporate social media, as an educational resource into their pedagogical practice successfully. The author's research aims are to: 1) examine the current relationship between social networking sites and pedagogy, 2) distinguish factors that influence teacher engagement with social networking sites in their pedagogical practice, 3) determine, using a mixed methods approach, whether or not social media engages students \& enhances academic performance more than traditional teaching methods, and 4) design a framework for teachers to follow when implementing social media strategies in the classroom.

\section{Literature ReVIEW}

Direct links between education and TEL are long standing, especially in 'numeric' uses of computers, (for example, pocket sized calculators). HE Institutions had begun using computers for teaching, and learning as well as for research and administrative purposes in the early 1960s (Selwyn, 2016). As the 1960s progressed, the use of computers in 'non numeric' forms such as tutorial and coaching instruction became popular and the term 'computer assisted instruction' was heralded by the philosopher, Patrick Suppes. Computer tutors, where a computer presents material to a learner and asks questions about it, ensured the equitable future of educational provision, allowing everyone access to top-quality teaching and learning (Suppes, 1966).

Social media was traditionally designed to pursue social activities and to create an 'online community for us all' (Zuckerberg, 2017). This included creating social profiles and engaging in digital dialogue, it was not one of education or learning support (Junco et al., 2013; Beetham, 2015; Purvis et al., 2016). Educators are now discovering that social media goes beyond personal need and links into educational contexts where it can contribute to a digitally competent graduate (Seaman and Tinti-Kane, 2013).

The use of social media in HE has delivered positive outcomes, including evidence of increased student engagement and increased grades (Junco et al., 2011; Ratneswary \& Rasiah, 2014; Landson et al., 2015; McKay et al., 2014; Tess, 2013). Although HE institutes 
are much more responsive to the SNS than the education sector in general, they have delivered some 'pushback' over concerns around e-professionalism and digital safety (Lupton, 2014). A study by Purvis et al. (2016) looked at the experiences of social media in $\mathrm{HE}$ after introducing optional workshops requested by staff to give them confidence using social media in their teaching and learning. The authors found that most staff, with the exception to some in journalism saw social media as an optional element to add to their curriculum and were increasingly confident with wikis and the VLE. Furthermore, those who used social media to enhance course community, facilitate autonomous and creative learning, and develop public facing professional portfolios, were the most confident members of staff in SNS. A lack of confidence was perceived as the main barrier for not using particular learning tools with some educators confessing to being a 'technophobe'. Where confidence was high and support available, the uptake of social media as a technology enhanced learning tool was more prevalent and successful.

Table 1: Examples of how Twitter can be used in the classroom

\begin{tabular}{ll}
\hline Category & Example of activities \\
\hline Communicating & Teacher posting course materials (Bahner et al. 2012; Blessing et al. 2012) \\
& Students using a common hashtag to tweet and communicate (Bista, 2015; \\
& McKenzie, 2014) \\
& Students tweeting in French to practice the language (McKenzie, 2014) \\
\hline Assessing & Students creating tweets using specific contents learnt during class time \\
& (Cacchione, 2015) \\
& Teacher posting surprise questions in class on Twitter (Kim et al., 2015) \\
& Students debate and discuss on Twitter (Tur and Marin, 2015 cited in \\
& Tang and Hew, 2017) \\
& Students answer questions via direct message after class (Chen and Chen, 2012) \\
& Students tweet their answers in response to questions which were worth \\
& 5\% of the overall course grade (Rohr et al., 2015) \\
\hline Collaborating & Students creating a joint diary/log on their timeline (Kassens-Noor, 2012) \\
& Students coordinating a time in a volunteer project (Junco et al., 2011; \\
& Junco et al., 2013) \\
& Using Twitter to negotiate time and groups (Junco et al., 2011)
\end{tabular}

Twitter is a microblogging SNS that allows users to follow people or organisations and post their own 'tweets' to engage with their own followers. Tang and Hew (2017) define Twitter as 'one of microblog services that allow users to send and receive information realtime'. The real time functionality means Twitter is dynamic and that the multimodal content is continuously changing over time. This may appear obvious, however content on other interactive educational portals such as university Blackboard, Moodle and Abyasa often remain static. Likewise, Twitter is free, meaning educational resources can be shared from all over the world at no cost, hence why teachers have exploited Twitter in various studies, durations and disciplines (Haythornthwaite, 2016; Junco et al., 2011; Landson et al., 2015). The benefits of using Twitter expand beyond connecting with fellow professionals, as in education where it has been documented to promote learning and improve engagement (Lewis, 2017; McKay et al., 2014; Junco et al. 2011). However, right now, educators mainly use Twitter for communication purposes outside the classroom (Tang and Hew, 2017; Alias et al., 2013; Buettner, 2013; Shabgahi et al., 2013). 
Haythornthwaite (2016) presented a case study which shows Twitter among the top two learning tools an educator expressed an interest in working with in the classroom, with $69 \%$ enthusiastic about Twitter. Thus, it is imperative that researchers and educators alike, know the successful and meaningful incorporations of Twitter and what can be further improved. (Tang and Hew, 2017). Previous applications of Twitter are shown in Table 1. The categories have been inspired through Tang and Hew's (2017) work.

\section{CPD AND TEL}

Teachers have reported that time out of lesson attending PD workshops that did not directly benefit their teaching was wasteful, therefore any training in TEL must help them successfully integrate technology into their classroom instruction. Keengwe et al. (2009) argues that there are a range of issues that schools are not addressing to successfully implement TEL, and proposes five strategies educational institutes can make for technology integration. Rodriguez, \& Knuth (2000) argue that for effective integration of technology, the following components must be met in CPD: connection to student learning, hands on technology use, variety of experiences, curriculum specific applications, and new role for teachers, collegial learning, active participation, ongoing process, sufficient time, technical support, adequate support, and administrative set up. In summary, for effective implementation of TEL teachers must have CK, PK and TK (Koehler \& Mishra, 2008), and the training required to develop teachers to this point must take into account their personal, social and professional variables. In particular, the training must consist of ongoing processes, and technical support.

\section{Theoretical Perspective}

The theoretical perspective used in this research is through the lens of the socio-cultural theory (Trowler, 2008). The significance of this is that it allows teaching and learning to be viewed in relation to recurrent practices in a social rather than a purely individual context. Socio-cultural theory suggests that learning is a social process that stresses interactions between people and tools.

\section{Methodology}

\section{Participants}

Initially, participants were recruited by making contact with the educational institute, and requesting if an introductory email along with the survey link could be circulated to their teaching staff; further recruitment also took place on Twitter. Making contact with schools proved very useful and the majority of surveys were completed this way. Nevertheless, the author found Twitter advantageous in reaching audiences from the education sector based throughout the U.K. Recruitment of participants took 10 months in total. In total, 411 participants $(n=411)$ completed the online survey and 20 participants $(n=20)$ took part in the interview.

\section{Instruments}

The present study adopted a mixed methods methodology that consisted of a three-phase data collection approach. Mixed methods research (MMR) is often referred to as the 'third methodological movement' and has been chosen in this study due to the significance highlighted earlier in moving 'beyond the paradigm wars' (Polio, 2012:294; Johnson et al., 2007). The first phase included an online survey with 11 closed questions and 3 five-point Likert rating scales. Many of the questions were made up of categorical variables, whereby the 
variable has categories as values. Some examples within the survey include 'Yes' and 'No', and 'Facebook', 'Instagram', 'Pinterest', 'Snapchat', 'Twitter', 'WhatsApp', 'YouTube', and 'other'.

The second phase included semi-structured interviews with a purposeful sample who met the eligibility criteria of being an active secondary teacher with QTS. The interviews were conducted on either Microsoft Teams, Skype, Zoom, or Google Hangouts, and the author was flexible in allowing the participant to choose their preferred platform. Phase two begun once key themes had been derived from the quantitative survey findings and converted into questions where they could be explored in greater depth in a qualitative way. Phase three involved returning to selected participants in a loose interview structure with the main purpose of solely exploring the final themes of this study.

\section{Analysis}

In this study, the author presents data using descriptive statistics as a form of analysis. The main aim of organizing the data this way is so they can be easily understood by providing simple graphics in graphs, charts and tables. The data is also presented in a way whereby frequencies and percentages of responses are shown. The theoretical freedom that thematic analysis brings to this piece of work provides a rich and detailed account of data that can be easily grasped by researchers early in their career, and this is evidenced in earlier studies by Braun \& Clarke (2006), King (2004), and Nowell et al. (2017). Furthermore, thematic analysis is useful in summarizing key features of large data sets as it forces the researcher to take a well-structured approach that helps highlights similarities and differences to generate a clear final report (King, 2004). Hence, thematic analysis was used to analyze the qualitative part to this study.

\section{RESULTS}

Phase 1

The following section is a selection of the survey questions that have been further explored in phase 2 .

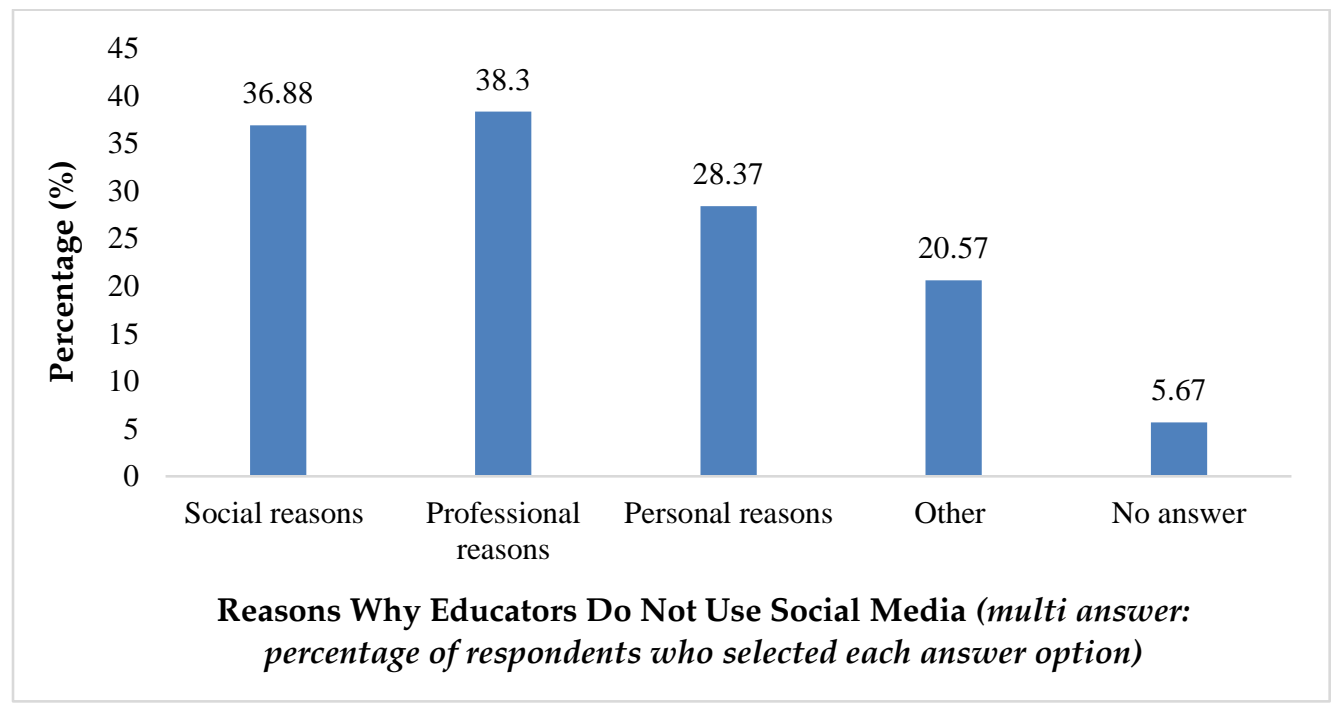

Figure 1: Reasons why educators do not use social media in their pedagogy 


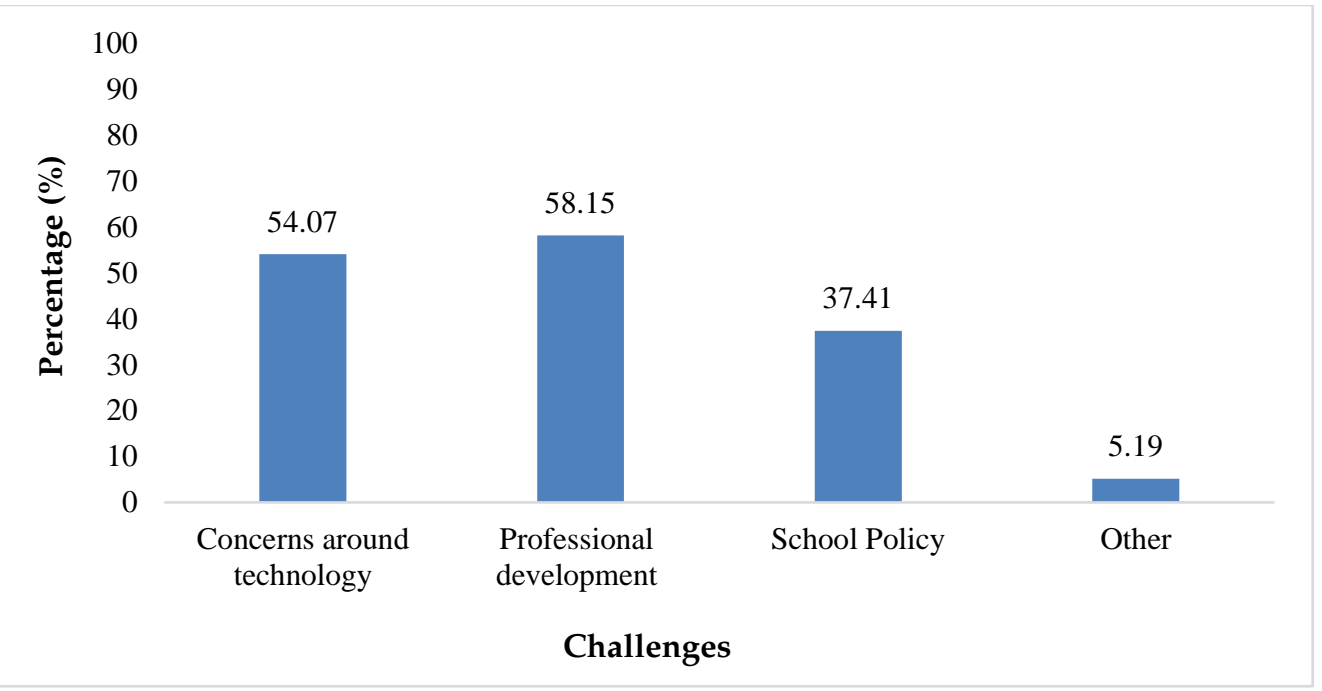

Figure 2: Views on the most challenging aspects associated with social media in the classroom

\section{Phase 2:}

Whilst teachers acknowledge the importance of being 'social media savvy', CPD appears to be less developed in this area. Broadly speaking, CPD in TEL appears to lack any pedagogical thought, with much of the training that takes place focusing on how to use the technology and other administrative uses such as how to book iPads out to use.

“...teachers certainly need to be skilled up on social media..." Steven

“...CPD happens every year on how students can keep safe and recently social media has played a part in these sessions. It is run by our pastoral team so every teachers gets the opportunity to take part..." Nicole

"...we do overt CPD on how to use the platforms we have in school..." Katy

"...when we got the iPads we were supposed to have training on it but never did..." Mike

"...we have staff training on a Monday and its everybody in one room for 1 hour, and senior leadership would basically just 'big up' the iPads and talk about how to book them out but never how to teach with them..." Philip

"...this is interesting because I was taking about this with a colleague, the TEL training doesn't actually link into the curriculum..." Roger

However, there are some school leaders who evidence successful TEL CPD with pedagogical thought.

"...I am actually in charge of the CPD in this area. We have a Google site where we have user guides and videos on how to use all the IT stuff in our school... it doesn't make sense for one person to be the gatekeeper when it comes to technology. Our site shows examples of how Google Chat, Forms and Classroom have been used in English, Art, Maths...it's the administrative side such as how to do a screen recording, but also links into the pedagogy..." Philip. 


\section{Discussion}

There is a wide consensus that technology can improve the teaching and learning in schools and other educational institutes (Selwyn, 2016; Gao et al., 2017; Fox, 2013) and in the U.K., this has led to commitment in supporting technology being used in the classroom (Party, 2017). However, there are questions that challenge if teachers are prepared to effectively use technology in their classroom (Polly \& Brantley-Dias, 2009). Even more so, there is no reference to the word 'technology' in the Teachers' standards (Department of Education, 2017). Some teachers are aware of this and this makes it difficult to see the value in such training when it is not linked to the curriculum.

It is important to note that, teachers' technological skills do not always translate into the effective use at a pedagogical level in secondary settings. Yet, much of the CPD around technology tends to focus on improving technological skills, thus is disconnected from 'methods courses' and how technology can be effectively implemented into the classroom. This is evidenced in this study with many teachers reporting to having undertaken training that involved 'how to book iPads' out to use rather than how will this tool improve the quality of teaching. This interesting theme has implications for the possibility of social media being successfully incorporated into pedagogy. In order for a teacher to successfully implement technology, they must have an understanding of how the technology knowledge works and is related to technology with content (in other words, how does this relate to students' learning, and technology with pedagogies and how can I teach with this?). There are some good examples highlighted in this study, such as a 'double dip' method where teachers acted as students for the training sessions in order to provoke thought on pedagogy.

As teachers become more knowledgeable about the benefits of TEL and comfortable with the use of technology in pedagogy, it is predicted that practices with integration of technology will improve (Keengwe et al., 2009). Thus, CPD must attempt to provide opportunities that will impact teachers' beliefs in technology. For example, Ertmer (2005) proposes that teachers must have first-hand experience with technology, where they can observe successful implementation from another teacher or educational professional. This would allow teachers to follow a 'gold standard' of practice which is more productive than admiring the technology out of context (Koehler \& Mishra, 2008).

\section{Other EMERGing THEMES}

Historically, the implementation and application of TEL must fit around regimes such as timetabling, curriculum and school governance. In this instance, the term TEL could be viewed as an overgeneralization, whereby some TEL products, in particular with new technologies such as social media are used outside of the classroom and profession by the educator. This is in contrast to previous uses of TEL in the classroom, such as personal computers or calculators which were primarily used in education and before the general population. This insight indicates the complicated relationship between TEL and education, and it is anticipated that the term TEL could be perceived as problematic.

\section{Conclusion}

The author is completing analysis on phase 2 and working towards data collection in the remaining interviews for phase 3. Further themes are to be published as part of the author's PhD thesis. 


\section{REFERENCES}

Alias, N., Sabdan, M. S., Aziz, K. A., Mohammed, M., Hamidon, I. S., \& Jomhari, N. (2013). Research trends and issues in the studies of Twitter: A content analysis of publications in selected journals (2007e2012). Procedia-Social and Behavioral Sciences, 103,773e780.

Bahner, D. P., Adkins, E., Patel, N., Donley, C., Nagel, R., \& Kman, N. E. (2012). How we use social media to supplement a novel curriculum in medical education. Medical Teacher, 34(6), 439-444. https://doi.org/10.3109/0142159X.2012.668245

Beetham, H. (2015). Thriving in a connected age: digital capability and digital wellbeing.

Bista, K. (2015). Is Twitter a Pedagogical Tool in Higher Education? Perspectives of Education Graduate Students. Journal of the Scholarship of Teaching and Learning, 15(2), 83-102. https://doi.org/10.14434/josotl.v15i2.12825

Blessing, S. B., Blessing, J. S., \& Fleck, B. K. B. (2012). Using Twitter to Reinforce Classroom Concepts. Teaching of Psychology, 39(4), 268-271. https://doi.org/10.1177/0098628312461484

Braun, V., \& Clarke, V. (2006). Using thematic analysis in psychology. Qualitative Research in Psychology, 3, 77-101.

Buettner, R. (2013). The utilization of Twitter in lectures. GI-Jahrestagung, p 234- 254

Cacchione, A. (2015). Creative use of Twitter for dynamic assessment in language learning classroom at the university. Interaction Design and Architecture(s) Journal- IxD\&A, N.24, 145-161. http://www.mifav.uniroma2.it/inevent/events/idea2010/doc/24 9.pdf

Chen, L., \& Chen, T. L. (2012). Use of Twitter for formative evaluation: Reflections on trainer and trainees' experiences: Colloquium. British Journal of Educational Technology, 43(2), E49eE52. http://doi.org/10.1111/j.1467-8535.2011.01251.x

Department of Education. (2017). Teachers' $\quad$ standards. Gov.uk. https://www.gov.uk/government/publications/teachers-standards

Ertmer, P. A. (2005). Teacher pedagogical beliefs: The final frontier in our quest for technology integration?. ETR\&D 53, 25-39.

Ferguson, C. (2013). It's time for the nursing profession to leverage social media. Journal of Advanced Nursing. Wiley Online Library, 69(4), pp. 745-747.

Fox, K. (2013). Twitter in the Classroom. Centre for Learning and Teaching 13(1) pp.1-3.

Freberg, K., \& Kim, C. M. (2018). Social Media Education: Industry Leader Recommendations for Curriculum and Faculty Competencies. Journalism \& Mass Communication Educator, 73(4), 379391. https://doi.org/10.1177/1077695817725414

Gao, Q., Yan, Z., Wei, C., Liang, Y., \& Lei, M. (2017). Three different roles, five different aspects: Differences and similarities in viewing school mobile phone policies among teachers, parents, and students. Computers and Education 106(3), 13-25.

Haythornthwaite, C. (2016). E-learning and new learning cultures and case: Social media in higher education [PowerPoint slides]. The University of Hong Kong.

Johnson, R., Onwuegbuziy, A., \& Turner, L. (2007). Toward a definition of mixed method research. Journal of Mixed Method Research, 1.112-133.

Junco, R., Elavsky, C.M. and Heiberger, G. (2013), Putting twitter to the test: Assessing outcomes for student collaboration, engagement and success. British Journal of Educational Technology, 44: 273-287. https://doi.org/10.1111/j.1467-8535.2012.01284.x

Junco, R., Heibergert, G. \& Loken, E. (2011). The effect of Twitter on college student engagement and grades. Journal of Computer Assisted Learning, 27, 119-132.

Kassens-Noor, E. (2012). Twitter as a teaching practice to enhance active and informal learning in higher education: The case of sustainable tweets. Active Learning in Higher Education, 13(1), 921. https://doi.org/10.1177/1469787411429190 
Keengwe, J., Onchwari, G., \& Onchwari, J. (2009). Technology and Student Learning: Towards a Learner-Centered Teaching Model. AACE Journal, 17(1), 11-22. https://eric.ed.gov/?id=EJ830564

Kim, Y., Jeong, S., Ji, Y., Lee, S., Kwon, K. H., \& Jeon, J. W. (2015). Smartphone response system using Twitter to enable effective interaction and improve engagement in large classrooms. IEEE Transactions on Education, 58(2), 98-103.

King, N. (2004). Using templates in the thematic analysis of text. In Cassell, C., Symon, G. (Eds.), Essential guide to qualitative methods in organizational research (pp. 257-270). London, UK: Sage.

Koehler, M. J., \& Mishra, P. (2008). Introducing tpck. Handbook of technological pedagogical content knowledge (TPCK) for educators, 1(1), 3-29.

Landson, M., Straker, K., \& Igbo, I. (2015). Adapting a Social Media Strategy in the Classroom: PEET. The Journal of Nursing Education, 54(10), pp. 600.

Lewis, T. L. (2017). Social media and student engagement in anatomy education. Anatomical Sciences Education, 10(5), pp. 508-508.

Lupton, D. (2014). Feeliing Better Connected Available Use Of Social Media Media Research Centre, University of Canberra.

McKay, M., Sanko, J. S., Shekhter, I., Birnbach, D. J. (2014). Twitter as a tool to enhance student engagement during an interprofessional patient safety course. J Interprof Care. 28(6), 565-567. https://doi.org/10.3109/13561820.2014.912618

McKenzie, B. A. (2014). Teaching Twitter: Re-enacting the Paris commune and the battle of $\begin{array}{llll}\text { stalingrad. The History 355-372. } & \text { Teacher, }\end{array}$ http://www.societyforhistoryeducation.org/M14Preview.html

Nowell, L. S., Norris, J. M., White, D. E., \& Moules, N. J. (2017). Thematic Analysis: Striving to Meet the Trustworthiness Criteria. International Journal of Qualitative Methods. https://doi.org/10.1177/1609406917733847

Party, C. (2017). Forward Together: Our Plan for a Stronger Britain and a Prosperous Future: the Conservative and Unionist Party Manifesto 2017. Conservative Party.

Polio C. (2012) No paradigm wars please! Journal of Second Language Writing. 21: 294-295.

Polly, D., \& Brantley-Dias, L. (2009). TPACK: Where do we go now? Tech Trends, 53(5) 36-47. http://dx.doi.org/10.1007/s11528-009-0324-4

Purvis, A., Rodger, H. M., Beckingham, S. (2016) 'Experiences of Social Media in Higher Education: Barriers, Enablers and Next Steps. Social Media for Learning in Higher Education', Conference Proceedings 2015, Sheffield Hallam University, pp. 0-17.

Ratneswary, R. and Rasiah, V. (2014) Transformative Higher Education Teaching and Learning: Using Social Media in a Team-Based Learning Environment. Social and Behavioral Sciences 123, 369-379

Rodriguez, G., \& Knuth, R. (2000). Providing Professional Development for Effective Technology Use. North Central Regional Educational Laboratory Critical Issue. Retrieved from http://www.ncrel.org/sdrs/areas/issues/methods/technlgy/te1000.htm.

Rohr, L. E., Costello, J., \& Hawkins, T. (2015). Design considerations for integrating Twitter into an online course. The International Review of Research in Open and Distributed Learning, 16(4).

Seaman, J. and Tinti-Kane, H. (2013) Social media for teaching and learning: Annual [Pearson] survey of social media use by higher education faculty.

Selwyn, N. (2016). Education and technology: Key issues and debates. Bloomsbury Publishing.

Shabgahi, S. L., Shah, N. A. K., \& Cox, A. M. (2013, July). A comparative review of research literature on microblogging use and risk in organizational and educational settings. In International 
Williams: An Explaration into the Pedagagical Benefits of Using Sacial Media: Can Educators Incorporate Sacial Media inta Pedagogy Successfully? (69-78) conference on online communities and social computing (pp. 174-181). Springer, Berlin, Heidelberg.

Suppes, P. (1966). Models of data. In Studies in logic and the foundations of mathematics, Elsevier, Vol. 44, 252-261. https://doi.org/10.1016/S0049-237X(09)70592-0

Tang, Y. \& Hew, K. (2017). Using Twitter for education: Beneficial or simply a waste of time?. Computers \& Education. 106. 97-118

Tess, P. A. (2013) 'The role of social media in higher education classes (real and virtual)-A literature review', Computers in Human Behavior.

Trowler, P. (2008) Cultures and change in higher education: Theories and practice. Basingstoke: Palgrave Macmillan.

Tur, G., \& Marin, V. I. (2015). Enhancing learning with the social media: Student teachers' perceptions on Twitter in a debate activity. Journal of New Approaches in Educational Research, 4(1).

Zuckerberg, M. (2017, February 16). Building Global Community [Blog Post]. Facebook. https://www.facebook.com/notes/mark-zuckerberg/building-globalcommunity/10103508221158471/?pnref=story

$--0--$

\section{How to cite this article}

Williams, R. T. (2020). An Exploration into the Pedagogical Benefits of Using Social Media: Can Educators Incorporate Social Media into Pedagogy Successfully? A work in progress. $A B C$ Journal of Advanced Research, 9(2), 69-78. https://doi.org/10.18034/abcjar.v9i2.532 